\title{
BAIL: AN ANCIENT PRACTICE REEXAMINED
}

THE modern institution of release on bail pending trial has evolved from a practice which goes back at least to pre-Norman England. The process of change, however, seems to have occurred without any clear perception of the functions bail ought to serve, with the result that the institution of bail currently consists of an incoherent amalgam of old and new ideas serving more to defeat than to achieve the aims of the criminal process. ${ }^{1}$

Since the general notion of bail pending trial antedates recorded English law, ${ }^{2}$ its original raison d'etre is not altogether certain. It probably arose from the medieval sheriff's desire to avoid the costly and troublesome burden of personal responsibility for those in his charge. ${ }^{3}$ Trials were delayed by the infrequent visits of itinerant justices, ${ }^{4}$ and many accuseds died because of unsanitary conditions in the prisons. ${ }^{5}$ Whether motivated by a concern for their prisoners' well being, or by a desire for pecuniary gain, ${ }^{6}$ sheriffs commonly released prisoners either on their own recognizances, with or without requiring the posting of some sort of bond, or on the promise of a third party to assume personal responsibility for the accused's appearance at trial. ${ }^{7}$ These ad hoc arrangements between sheriff and accused were not systemized and codified into the English legal framework until the Statute of Westminster. ${ }^{8}$ The statute attempted to standardize the practice of bail. It specified the conditions under which pretrial release was permissible, limited the power of the sheriff to determining sufficient security in each case, a power subsequently transferred to justices of the peace. ${ }^{9}$ To ensure that the accused would reappear on the date set for his trial, a third party, or surety, had to assume a personal responsibility for the accused, on penalty of forfeiture of his own property. ${ }^{10}$ In

1. This failure has long been recognized. See 1 National Comm. on Law OBs. \& ENF., Rep. on Prosecution 91 (1931) (Wickersham Report). See generally, Beeley, The BaIr Systemr in Chicago (1927) [hereinafter cited as Beetey]; Orfield, Criminal Procenure From ARREST to Appeal 130 (1947) [hereinafter cited as OrfieLd]; Foote, $A$ Study of the Administration of Bail in Neze York City, 106 U. PA. L. Rev. 693 (1958) (hereinafter cited as Nere York Bail Study).

2. See Stephen, A History of the Criatinal Law of England 233 (1883).

3. See 2 Polzock \& Mattland, The History of English law Before the Time of Edward I 584 (1899) [hereinafter cited as Pollock \& Matrland]. Sheriffs were heavily fined when escapes occurred. Morris, The Medieval English Sheriff to 1300, 88 (1927).

4. See Qasem, Bail and Personal Liberty, 30 Can. B. Rev. 378 (1952).

5. See Warner, Investigating the Lawe of Arrest, 26 A.B.A.J. 151, 152 (1940).

6. See MoRris, op. cit. supra note 3, at 98-99.

7. See Pollock \& MaItLand 585-90.

8. 1275, 3 Edw. I, c. 15. See generally Pollock \& Mattland 587.

9. $1360-1361,34 \mathrm{Edw}$. III.

10. See 4 Blackstone, Commentaries 380 (Hammond ed. 1890). See also Pollock \& Mattland 589-90:

English, Norman and French tradition seem all to point to an ancient and extremely rigorous form of suretyship or hostageship which would have rendered the surety 
practice, local landowners were preferred as sureties and were given the powers of a jailer to prevent the accused's flight. ${ }^{11}$ This system seemed eminently reasonable in an immobile land-oriented society.

In time, the granting or denying of bail in England became almost completely a discretionary function of the judiciary, and remains so today. ${ }^{12}$ In America, however, federal law and most state laws provided an absolute right to bail in all but capital cases. ${ }^{13}$ This emphasis on the individual's absolute right to bail led to practical difficulties in a large country whose frontier territories beckoned invitingly to those with a dim view of their chances for acquittal. The initial judicial reaction was to remind the party furnishing bail that he was a quasi-judicial officer with powers of a jailer, ${ }^{14}$ and that he was responsible for procuring the accused's attendance at trial. ${ }^{15}$ But since private sureties could not effectively conduct nationwide searches for their itinerant charges, ${ }^{10}$ their promise to produce the accused gradually became a promise merely to pay money should the accused fail to appear. ${ }^{17}$ This development

liable to suffer the punishment that was hanging over the head of the released prisoner. 590.

11. Sometimes even a whole township was made responsible. See Pollock \& Martland

12. See Orfiecd 102-04. For a recent interpretation, see Regina v. Campbell, 1 Weekly L.R. 646 (Liverpool Crown Ct. 1959). The English system has long guaranteed a right against "excessive bail." English Bill of Rights, 1689, 1 Wm. \& Mary 10.

13. The Judiciary Act of 1789 gave an absolute statutory right to bail (except in capital cases, where bail is discretionary) which has been operative throughout the history of the Republic. Today this rule is found in the FED. R. CRIM. P. 46(a) (1). For a collection of state provisions, see Appendix A.

The first American proscription against excessive bail antedates the English Bill of Rights. Mass. Body of Liberties 18 (1641). It was included in the eighth amendment to the United States Constitution, which applies only to federal courts. Collins v. Johnston, 237 U.S. 502 (1915).

Mr. Justice Black has suggested that, contrary to its meaning in England, the proscription against excessive bail in American law assumed that there was an absolute right to bail. See Carlson v. Landon, 342 U.S. 524, 557 (1952) (dissenting opinion). Compare Bridges v. California, 314 U.S. 252, 263-68 (1941); United States v. Motlow, 10 F.2d 657, 659 (7th Cir. 1926). But see Carlson v. Landon, 342 U.S. 524, 545 (1952) ; Comment, 51 MITH. L. REv. 389 (1953).

14. See Taylor v. Taintor, 83 U.S. (16 Wall.) 366,371 (1872) ("their dominion is a continuance of the original imprisonment"); Commonwealth v. Bricket, 25 Mass. (8 Pick.) 137 (1828) ("If the door should not be opened at midnight, the bail may break it down, and take the principal from his bed."); State v. Lingerfelt, 109 N.C. 775, 14 S.E. 75 (1891) ( upholding the bail's use of deadly force in capturing the principal); Nicolls v. Ingersoll, 7 Johns. (N.Y.) 145 (1810).

15. See Taylor v. Taintor, supra note 14.

16. Some observers at one time believed that since the bondsmen were in many instances related to the underworld syndicates, see note 40 infra, they might have more "efficient" means of discovering the whereabouts of itinerant principals. This idea has not worked well in practice, because of the underworld code against aiding the police. (Personal interviews with police officials and bondsmen).

17. "The distinction between bail and suretyship is pretty nearly forgotten. The interest to produce the body of the principal in court is impersonal and wholly pecuniary." Leary 
ushered in the professional bondsman who saw an opportunity for financial gain. In return for the payment of a fee, the bondsman would post a bond on behalf of the accused. The risk involved was minimized by the fact that courts, still viewing the bondsman as one obligated to produce the accused, either waived or refunded a substantial percentage of forfeitures on the theory that the bondsman had used "reasonable diligence" to prevent the accused's escape. ${ }^{18}$ More important, even these forfeitures which were imposed often could not be collected because of the prevalence of "straw bondsmen"-sureties with insufficient assets to meet their obligations. ${ }^{10}$

State legislatures reacted by placing statutory limits on premium rates and requiring the bondsman to prove his ability to meet the financial obligations he had undertaken. ${ }^{20}$ The requirement of a dollar-for-dollar matching of all liabilities undertaken led to the entry of insurance companies into the field. These companies were able to supply the requisite financing now beyond the means of individual bondsmen. Indeed, New York prohibited the conduct of a private bail bond business by anyone other than a licensed insurance company. ${ }^{21}$ Insurance companies recruit private bondsmen, to act as subagents. The bond "premium" is allocated between the company and the bondsman, but a portion of the latter's share is retained by the company in a "build-up" fund from which losses attributable to a given bondsman's "clients" are absorbed. ${ }^{22}$ The

v. United States, 224 U.S. 567, 575 (1912) (dictum). For an atypical survival of the suretyship theory, see Concord Cas. \& Sur. Co. v. United States, 69 F.2d 78, 81 (2d Cir. 1934) (dictum).

18. It has been estimated that from one-third to two-thirds of the forfeitures in Chicago between 1908 and 1925 were vacated. BeEzey 47-56. In Philadelphia in 1950 only 20\% of the forfeitures were collected. Foote, Compelling Appearance in Contrt: Administration of Bail in Philadelphia, 102 U. PA. L. REv. 1031, 1062 (1954) [hereinafter cited as Philadelphia Bail Study]. For the rationale behind forfeiture vacation, see People v. Fiannaca, 306 N.Y. 513 (1954).

19. See e.g., People v. Froelich, 110 App. Div. 873, 874, 96 N.Y. Supp. 488, 489 (1905); Sims, Speedy Justice in Criminal Cases, 46 A.B.A. REP. 596, 601 (1921).

20. See, e.g., N.Y. Code Crim. Proc. § 554-b. Perhaps the first statute aimed at controlling "straw bondsmen" was 21 James I, c. 8 (4\& 5) (1623).

Courts of one city required $100 \%$ forfeitures. Detroit Recorder's Court Rules (rev. ed. 1951) ; see Detroit Court Solves Bail Problem, 16 J. Anr. Jud. Soc. 143 (1933).

21. N.Y. Code Crim. Proc. § 554-b (3) ; 1927 Ops. N.Y. ATt'y Gen. 163 (a corporation 'engaged "in the business of giving bail" must be one entitled to carry on "the business of insurance") ; see People v. Smith, 196 Misc. 304, 307, 91 N.Y.S.2d 490, 494 (1949).

22. See the detailed description of the bail situation in Brooklyn, New York, contained in a Letter From Judge Nathan Sobel to the Yale Law Journal, on file at the Yale Law Library.

\begin{tabular}{ccccc}
$\begin{array}{c}\text { Amount of } \\
\text { Bond }\end{array}$ & $\begin{array}{c}\text { Statutory } \\
\text { Fee }\end{array}$ & Insurer & Bondsman & Build-up-Fund \\
\hline$\$ 1,000$ & $\$ 50$ & $\$ 20$ & $\$ 30$ & $\$ 5$ \\
2,000 & 90 & 40 & 50 & 10 \\
5,000 & 180 & 100 & 80 & 25 \\
10,000 & 330 & 200 & 130 & 50 \\
25,000 & 780 & 500 & 280 & 125 \\
\hline
\end{tabular}


insurance companies thus take little or no risk. ${ }^{23}$ Bondsmen, in turn, protect their interest in the build-up fund by requiring accused persons to put up collateral equal to the amount of their bond. ${ }^{24}$ Bail systems similar to this currently exist in most American states.

The original reasons for releasing prisoners pending trial are, of course, no longer valid. But a different and less pragmatic justification for pretrial release has been developed. It emphasizes the importance of the presumption of innocence in our system of criminal justice, ${ }^{25}$ and decries the imposition of sanctions prior to trial and conviction. ${ }^{26} \mathrm{~A}$ related purpose is to give the accused maximum opportunity to prepare his own defense. In many cases, the accused may be the only person who can identify potential witnesses, or who can win their confidence in learning the whereabouts of others. ${ }^{27}$

23. Judge Sobel, supra note 22, writes that,

The amount of these build-up funds varies between the companies and even with respect to each of its agents depending on the amount of business written. But each fund is sufficiently large to protect the insurer against loss by forfeiture. All forfeitures are met out of these build-up funds. I have inquired of the larger bail bondsmen and they have advised me that in their experience, the insurer has never had to meet any loss in excess of the build-up fund. It may have happened on a rare occasion but if it did it is so rare as not to be commonly known in the business.

In the eyes of the surety companies,

bail bonds . . . are not insurance. When a company issues such an undertaking it does not contemplate any loss whatsoever. It merely guarantees that the principal will appear for trial and sentence, if convicted. Where there is any doubt about the prisoner's willingness to return, the surety demands full collateral so as to be in a position to cover the forfeiture if the principal disappears.

Letter From Philip Morehouse, Assistant Secretary of the Surety Ass'n of America to the I'ale Law Journal on file Yale Law Library.

24. See Note, 35 VA. L. Rev. 496 (1949). This practice represents a complete reversal of the suretyship concept, under which anything that encouraged the surety to relax his vigilance was held illegal. For example, an action of indebitatus assumpsit by the bail against the principal was not allowed, see United States v. Ryder, 110 U.S. 729 (1884), and the acceptance of an indemnification contract was illegal, see United States v. Simmons, 47 Fed. 575 (C.C.S.D.N.Y. 1891). In England it was a crime for a surety to accept property from his principal. See Rex v. Porter, 26 T.L.R. 220 (Crim. App. 1909).

25. See Stack v. Boyle, 342 U.S. 1, 4 (1951) ; State v. Konigsberg, 33 N.J. 367, 373 (1960).P. 4.

26. "The sole purpose of restraint before conviction is to secure the presence of the accused for trial." State v. Kauffman, 20 S.D. 620, 108 N.W. 246 (1906); accord, United States $c x$ rcl. Rubenstein v. Mulcahy, 155 F.2d 1002, 1004 (2d Cir. 1946). Restraint for other reasons has been decried. Williamson v. United States, 184 F.2d 280, 282 (2d Cir. 1950) (MIr. Justice Jackson as Circuit Judge) ("Imprisonment to protect society from predicted but unconsummated offenses is so unprecedented in this country and so fraught with danger of excesses and injustice that I am loath to resort to it ..."); State v. Patterson, 108 So. 2d 448 (Ala. 1958) ; Ford v. Dilley, 174 Iowa 243, 156 N.W. 513 (1916) (to prevent tampering with state's evidence); Commonwealth v. Davies, 1 Binney (Pa.) 97 (1804) (fear of continued offenses).

27. Student directors of the Yale Law School Public Defender Association report that Negroes are most reluctant to talk to white people regarding any criminal matter. They 
In theory, if the presumption of innocence is to be given full effect, all prisoners ought to be unconditionally released before trial. But a countervailing consideration has limited the scope accorded this presumption. The state must make sure that the accused will appear for trial. It is on this ground that the requirement of posting bond is justified-a financial deterrent to flight. ${ }^{23}$ For the same reason the otherwise absolute right to bail has been made discretionary with the judge in capital offenses, on the theory that the likelihood of flight is increased where a man is given the "choice between hazarding his life before a jury and forfeiting his or his sureties' property." ${ }^{29}$ Even here, however, additional factors might indicate that the risk of flight is insubstantial, and one court has stated that in such cases discretion should be exercised in favor of release. ${ }^{3 n}$

An examination of the workings of the present system indicates that it is unsuitable for the attainment of the aims it purportedly serves. The guaranty of a right to bail does not result in the release of prisoners pending trial. Because the bondsman often demands collateral, accused persons are, in effect, required either to provide their own bond or remain in jail. In New York, for example, 28 per cent of those required to make $\$ 500$ bail could not do so; 38 per cent could not make $\$ 1,000$ bail ; 45 per cent could not make $\$ 1,500$ bail; 63 per cent could not make $\$ 2,500$ bail ; 75 per cent could not make $\$ 5,000$ bail ; and 86 per cent could not make $\$ 7,500$ bail. ${ }^{31}$ In addition, the present system of bail does not provide an effective deterrent against flight. ${ }^{32} \mathrm{~A}$ judge who has no discretion to refuse bail is forced to reflect his fears concerning the likelihood of the accused's flight in the amount of bail he imposes. ${ }^{33}$ While a sufficiently high bail may effectively result in a denial of release, those prisoners who are able to make this high bail may not be deterred from flight by the thought of financial sacrifice. In the 13 th century when a man's wealth was likely to be exclusively tied to his

have found it impossible to locate Negro witnesses that the accused could probably find within a short period of time if permitted to search for them. But cf. United States v. McNann, 263 F.2d 940 (2d Cir. 1959).

Preparation of defense is also impeded indirectly. In many instances the detention pens, where accused persons are placed prior to trial, are in far more dismal condition than the prisons to which those actually proven guilty are sentenced. New York Bail Study 723-25. Many accuseds plead guilty in order to avoid the delay and frustration that await a decision to contest. Douglas, Vagrancy and Arrest on Suspicion, 70 YALE L.J. 1, 4 (1960); Nczo York Bail Study 727-29; Treuheft, Abolition of Bail in Misdemeanor Cases, 19 LAw. Gund Rev. 55, 56 (1959) ; United States v. Johnson, 238 F.2d 565, 573 (2d Cir. 1956) (Frank, J., dissenting).

28. See, e.g., Stack v. Boyle, 342 U.S. 1, 4 (1951).

29. State v. Konigsberg, 33 N.J. 367, 373 (1960).

30. Ibid.

31. New York Bail Study 707.

32. See generally, Hearings Before the Subcommittee on Making Bail Iumping a Separate Crime of the House Committee on the Judiciary, 83 Cong., 2d Sess. 2 (1954).

33. The amount of bail which can be set is not, of course, unlimited. See, e.g., United States ex rel. Rubenstein v. Mfulcahy, 155 F.2d 1002 (2d Cir. 1946) (reversing bail set at $\$ 500,000$ for wealthy financier accused of selective service violation). But see State v. Tweed, 63 N.Y. 202 (1875) (bail of $\$ 3,000,000$ for Boss Tweed upheld). 
land, the fear of losing that land might well have impelled him not to flee. Today, however, a defendant who has sufficient collateral to meet his bondman's requirements, or to post his own bond, ${ }^{34}$ is likely to have other liquid assets in excess of any amount he may forfeit, enabling him, in effect, to "buy" his freedom. Thus, the bail system neither accommodates the presumption of innocence, nor provides an effective deterrent against flight.

Additional factors militate against retention of the present system. In most instances society has refused to grant even to the judiciary discretionary power to refuse bail. ${ }^{35}$ It has, at least in principle, barred the imposition of "excessive bail," ${ }^{30}$ since this would be an obvious method of denying release. Yet, in practice, the decision to release an accused may be overridden by the bondsman, a private individual subject to none of the responsibilities or restraints imposed on the judiciary.

In the final analysis the fulfillment of the constitutional proscription pertaining to bail, reposes with the professional bail bondsman since he may refuse to write even the smallest bonds. The bondsman may act on whim or caprice and his decision is not reversible either in a court of law or by an administrative agency. The Supreme Court ... cannot require that a bondsman write a bail bond, no matter how arbitrary the bondsman's refusal. ${ }^{37}$

The bondsman's reasons for denying bail may be unrelated to the likelihood of flight. His discretionary power is often used to coerce defendants into paying illegal overcharges ${ }^{38}$ or using a favored attorney with whom the bondsman las a fee-splitting arrangement. ${ }^{30}$ This power may also be used to give preferent-

34. Under the common law, cash or property could not be accepted as or in liet of bail, and is acceptable now only when authorized by statute. See Badolato v. Molinari, 106 Misc. 342, 174 N.Y. Supp. 512 (Sup. Ct. 1919) ; e.g., N.Y. Code CRIM. Proc. $\$ 586$ (which permits cash or government securities to be given).

Judges in New York have adopted a policy in some instances of granting an alternative bail, e.g." " $\$ 1,000$ or $\$ 100$ cash." This procedure aids those accuseds who would have trouble raising collateral for a bondsman. But this alternative was only used in $1 \%$ of all cases in New York City in which bail was set. See Nezv York Bail Stıdy 719-20.

35. See Appendix.

36. Sce note 13 sulpra.

37. Report of the Third February 1954, Grand Jury of New York County, New York to Hon. John A. Mullen, at 2-3. For early recognition of this problem, see Note, 21 Colum. L. Rev. 592 (1921). See also Beeley 39-56; Note, 17 LAw GuIld Rev. 148 (1957):

38. Report of the Third February, supra note 37. See also Report of the Eighth March, 1948 Grand Jury of Kings County, New York to Hon. Samuel S: Leibowitz, at 2.

39. See note 38 supra; Funk, The Bondsman Problem, 19 KEN. S.L.B. 14 (1955) ; Letter From Howard E. Hurd, Assistant Deputy District Attorney of Los Angeles, California to the Yale Law Journal, on file Yale Law Library (suggesting the prevalence of this practice in Los Angeles until very recently.).

Legislatures and courts have taken some steps toward remedying this problem. Most of them have merely made "good moral character" a prerequisite to obtaining a license to enter the bail bond business. See, e.g., CAL. INS. CodE $\$ 1805$. See generally MCDonough v. Goodcell, 13 Cal. 2d 741, 91 P.2d 1035 (1939).

The earlier statutes placed the duty of administering the "good moral character" requirement on the various state insurance departments, but they were usually guilty of lax en- 
ial treatment to members of a criminal syndicate, which may in fact be the bondsman's employer. ${ }^{40}$

One plan for improving the system of pretrial release might be to reform the existing machinery. One way of doing this would be to recognize that the bondsman and the insurance company are merely adjuncts to an essentially public function, and that they should be regulated as such. The state might treat these companies like "common carriers," imposing a broad duty to provide their services to all who seek them. The companies would still receive a state-fixed premium but, just as at common law, ${ }^{41}$ could not require the accused to provide collateral. Such a system, however, while giving greater operative effect to the presumption of innocence, ${ }^{42}$ would not accommodate the goal of providing a deterrent against flight, since the accused would lose nothing by fleeing. It might be argued that a re-emphasis of the concept of the bondsman as a private "jailer" would serve this function. ${ }^{43}$ Perhaps, bondsmen without collateral would have a sufficient financial incentive to perform this function. But such a proposal is impractical and undesirable. The number of persons freed on bail is too great to permit personal supervision by bondsmen. ${ }^{44}$ In addition, it would be especially

forcement. See, e.g., Report of Eighth March 1948, Grand Jury of Kings County, New York, supra note 38 , at 3 . Some courts attempted to enforce the requirement, even in the absence of legislative authorization. E.g., Taylor v. Waddey, 334 S.W.2d 733 (Tenn. 1960); Summit Fid. \& Sur. Co. v. Nimitz, 158 Neb. 762, 64 N.W.2d 803 (1954) ; In re Carter, 192 F.2d 15 (D.C. Cir. 1951). Some legislatures specifically assigned the job to the courts. E.g., Ark. Reg. Sess. 1959, S.B. 332 \& 1(c) ; Va. Reg. Sess. 1958, House Bill 710 amending VA. CoDE ANN. § 58-3712; West Va. Reg. Sess. 1959, House Bill 42, art. 10, § 8. Such a nebulous standard as "good moral character" is unlikely to remedy the defects in the present system, however. In New York, at least, such a requirement has apparently had no effect. Report of the Eighth March, 1948 Grand Jury of Kings County, New York, supra note 38.

40. See, e.g., Report of Fifth March 1960 Grand Jury of New York County, New York to Hon. Charles Marks. The mechanics of this operation are that:

Each syndicate retains a bonding firm and an attorney to service members who are arrested. When a "runner" or "bagman" is absent from his scheduled rounds, routine release procedures are initiated. The bondsman, sometimes prematurely, checks with the police to determine if a syndicate man has been detained. If the missing man is in custody, the syndicate's attorney files an application for a writ of habeas corpus and appears before a magistrate who usually sets bail at a nominal amount and adjourns hearing the writ, at the request of the police, until the following day ... [the protection for collectors from police harassment] tends to consolidate control of the numbers racket in a few syndicates "big" enough to sustain the legal, bonding, and other "business" costs.

Goldstein, Police Discretion Not to Invoke the Criminal Process: Low-Visability Decisions in the Administration of Justice, 69 Y ALE L.J. 543, 582-83, 585 (1960).

41. See note 24 supra.

42. This would, of course, in no way affect the position of indigents and near indigents, who could not even afford the "premium." Cf. Treuheft, Abolition of Bail in Misdemeanor Cases, 19 Law. Gurn Rev. 55 (1958). Longsdorf, Is Bail a Rich Man's Privilege?, 7 F.R.D. 309 (1947).

43. See note 14 supra.

44. See Foote, Introduction: The Comparative Study of Conditional Release, $108 \mathrm{U}$. PA. L. Rev. 290, 300 (1960); Philadelphia Bail Study 1065-67. 
odious in a free society to unleash an army of private citizens with virtually unfettered police power.

In view of these limitations in the insurance company-bondsman machinery, a more radical solution is called for. It should begin by completely eliminating the bondsman and insurance company from the bail bond field. Since bondsmen generally require collateral, ${ }^{45}$ the accused's position would be unchanged if the state required him to deposit this collateral with the court as his security. Whatever financial deterrent to flight exists under the present system would be unaffected. ${ }^{40}$ The difference would be that judicial decisions to release on bail would no longer to subject to reversal by a bondsman. This modification, however, would be only a starting point. To establish a system of pretrial release which will accommodate the presumption of innocence and the desire to secure the attendance of an accused at trial, a thorough-going revision of other practices and assumptions is necessary.

The assumption that pretrial release must, in all cases, be conditioned on the posting of financial security should be discarded. If pretrial release is based upon the presumption of innocence, conditions should be placed upon that release only if they are justified by some countervailing policy, in this case the need to secure the accused's attendance at trial. ${ }^{47}$ By procuring arrest and arraignment of the accused, the state has already made a showing that there is probable cause to suspect the accused, ${ }^{48}$ and arguably this showing provides a basis for inferring some likelihood of flight. But to assume from this finding that all pretrial releases must be accompanied by financial conditions seems unwarranted. Even admitting that there is some incentive to flee in all cases, there are also many "natural" deterrents to flight which operate without the aid of the state. The individual must leave his job, his friends, often his family, and may also be forced to leave some wealth behind.49 Moreover, modern methods of identification, such as the nationwide exchange of fingerprint and photographic information by police, probably make the lure of other jurisdictions less attractive than in pioneer days. ${ }^{50}$ And although only three jurisdictions actually make bail-jumping a crime, ${ }^{51}$ the probability that attempted flight will result in greater punish-

45. See note 23 supra; New York Bail Study 704.

46. It might even be increased since this would lead to $100 \%$ forfeiture collection. Compare Philadelphia Bail Study 1064.

47. While preventing danger to the community from the accused has been suggested as another policy to justify imposing conditions, see ALI, Code of CrIMINaL Procedure $§ 70$ (1930), courts have expressed reluctance to confine suspects for such reasons, see cases cited note 26 stipra.

48. See Orfield 10.

49. In addition to immovable wealth, intangible benefits like social security, unemployment compensation, etc., will have to be left behind. It might be asserted that these factors are the real deterrent now in effect and that the imposition of a cash bond in most cases is mere surplusage. Cf. New York Bail Study 706.

50. In addition, anonymity has made unlikely the need for identification data for a multitude of purposes, such as getting a job, obtaining credit, or relief.

51. Minn. Stat. Ann. § 613.35; N.Y. Pen. LAW § 1694 (a); 18 U.S.C. 3146 (1958). For the contrary position, see, e.g., Collins v. Georgia, 32 Ga. App. 450 (1924) ("[T]here 
ment for the initial offense probably serves as another deterrent to flight in all others. $^{52}$ A system of pretrial release should recognize the existence of these deterrents, and should not impose other conditions upon pretrial release when natural deterrents alone seem to be adequate. ${ }^{53}$ Furthermore, its seems consonant with the presumption of innocence to provide that the burden of proving the need for greater deterrence should be on the state. ${ }^{54}$

To determine what deterrence against flight is necessary in individual cases, the existing guides to setting bail should be re-examined. In most cases, bail is set according to the offense. ${ }^{55}$ Gravity of the offense is of course relevant, for one might reasonably conclude that the incentive to flee will increase proportionately with the possible punishment awaiting the offender. ${ }^{50}$ But this factor should not be the only determinant. ${ }^{57}$ The accused's reputation in the community, his past record, and the presence or absence of ties in the com-

is no law in this state authorizing his punishment for contempt of court for failing and refusing to appear in accordance with the terms of the bond."). In fact a previous record of bail jumping has been held not to permit the judge to deny bail. Rowan v. Randolph, 268 Fed. 527 (7th Cir. 1920).

52. See Philadelphia Bail Study 1060.

53. The Grand Jury ... recommends . . that the courts . . .parole" . . all defendants who, consistent with the security of the community and the rights of the defendant, should be at liberty while awaiting trial.

Report of Third February 1954, Grand Jury of New York County, New York at 3; accord, Treuheft, Abolition of Bail in Misdemeanor Cases, 19 LAw. Gund Rev. 55, 56 (1959). See also New Zealand, Offenders' Probation Act \$ 5.15(c) (1920):

If a person is committed for trial for an offense punishable by imprisonment, and is unable to obtain bail for his appearance when required, the court may, in appropriatc cases, release him under probation supervision instead of sending him to prison to await his trial.

Although discretion is sometimes given to release a prisoner without bail, e.g., N.Y. CITY CRIM. C TS. ACr $\S 103$, such action has never been required, except to the extent that the imposition of bail in however small an amount may, in a given case, be held to be constitutionally "excessive." But see Ex parte Malley, 50 Nev. 248, 256 Pac. 512 (1927).

The discretionary power given to New York City magistrates to release prisoners without requiring bail has been exercised in only $2.9 \%$ of the cases in which it was available in 1957. See New York Bail Study 721.

54. Cf. State v. Konigsberg, 33 N.J. 367, 374-75 (1960) ("The burden should rest on the party relying on the exception. That is the logical and natural rule and the one which conforms with the pervasive presumption of innocence attending all criminal charges. In fact, there is an indissoluble connection between that presumption and the right to liberty before conviction.").

55. See Foote, The Bail System and Equal Justice, 23 FED. PRoв. 43, 46 (1959); Philadelphia Bail Study 1043 ("The individual is subordinated to the class into which he is placed according to the type of crime with which he is charged, although what relationship to the risk of nonappearance this may have is unknown.").

56. See FEd. R. Crins. P. 46(c); cf. Stack v. Boyle, 342 U.S. 1 (1951).

57. For a discussion of the number of relevant criteria, see Morse \& Beattie, A Survey of the Administration of Criminal Justice in Oregon, 11 ORE. L. REv. (Supp.) 1, 101-07 (1932). 
munity should all be considered. Another important determinant should be the likelihood of guilt. This factor is recognized, in another context, by statutes and constitutional provisions guaranteeing the absolute right to bail. The exception for capital offenses is generally phrased "except for capital offenses when the proof is evident or the presumption great." 58 If the weight of the evidence against the accused is relevant to the issue of whether he should be released on bail, presumably it has some relevance to his desire to flee. The premise is probably that innocent persons (or, more accurately, those with little evidence against them) will want to remain in the vicinity to prove their innocence. But this premise seems applicable to all offenders seeking pretrial release and should not be applied only in capital cases. The weight of evidence is, of course, only one factor among several to be considered, so that a specific test, such as "probable cause", would not have the same effect in all cases.

Once a substantial risk of flight is shown, the conditions imposed on release should not automatically result in the imposition of a financial deterrent. Of course, if the magistrate determines that risk of financial loss will be sufficiently meaningful to the particular accused, he might simply require the accused to deposit security with the court. But if it appears that risk of financial loss will not be a meaningful deterrent, because, for example, someone other than the accused is likely to supply his bail, ${ }^{59}$ other conditions must be sought. Similarly, if the accused is unable to provide security because he has no assets, other restrictions must be considered if imposition of bail is not to be used as a subterfuge for denial of release. ${ }^{60}$ These might include release in custody of a third party, such as the accused's employer, minister, attorney, ${ }^{61}$ or a private organization $;^{62}$ release subject to a duty to report periodically to the court or other public official; or even release subject to a duty to return to jail each night. Admittedly, the setting of individualized conditions poses a more difficult problem than the automatic imposition of bail. ${ }^{63}$ Yet if the risk of flight is not so great as to justify total subordination of the presumption of innocence, an attempt to find such conditions must be made.

If risk of flight is weighed individually as suggested, there will be noncapital cases where the risk is so great that absolute denial of pretrial release would be justified. Explicitly allowing denial of bail on these grounds would be con-

58. See Appendix. FED. R. CRIM. P. 46(c) provides for consideration of the "weight of the evidence" as one of the factors in setting bail.

59. See note 40 supra.

60. Thus financial conditions would only be imposed if they could be met. See KoREA, Code of Crrm. Proc., art. 98(2), transiation in YeARBooK on HuMAN RIGHTs 186 (1954) ("the court shall not fix bail money beyond the financial ability of the accused").

61. The efficacy of using court-appointed attorneys, however, is doubtful.

62. The Netherlands uses private organizations of probation work. See UNITED NAtrons-Departaient of Soctal Affatrs, Probation and Related Measures 172 (1951). Most of these are religious organizations.

63. Compare New York Bail Study 1070-71, with Morse \& Beattie, Survey of the Administration of Criminal Justice in Oregon, 11 ORE. L. REv. (Supp.) 1, 13 (1932). 
trary to the statutory and constitutional provisions of most jurisdictions. ${ }^{64}$ One commentator has concluded, however, that judges frequently do deny bail in such cases simply by setting bail so high that the accused cannot meet it. ${ }^{05}$ Open recognition of this practice would be advisable. The limitation of the power to deny bail to capital offense cases seems illogical, for the underlying policy of that exception-incarceration of those most likely to flee ${ }^{60}$-can hardly be satisfied by looking to capital offenders alone. ${ }^{67}$

More important, explicit recognition of the power to deny bail would help to promote safeguards against abuse, which are not likely to be encouraged when the power is not openly exercised. These should include keeping a record of the proceedings in which the prosecution challenges the accused's right to be released. The magistrate should be required to articulate for the record the reasons underlying his determination. In any case in which the accused is denied even conditional release there should be some avenue of immediate review. For example, the accused might be given the right to a hearing de novo before a judge of the next highest court of general criminal jurisdiction in the state, no later than, say, one week following the initial determination. In the event the decision to deny release is confirmed, in capital or noncapital cases, further safeguards must be taken to secure speedy trial. ${ }^{68} \mathrm{~A}$ long period of pretrial detention may not only be unjustified punishment in itself, but it may also serve prosecutors and police with a weapon for coercing confessions, or for. bargaining with a weak case for a plea of guilty on a lesser charge. ${ }^{60}$ The general practice of deferring to the prosecutor's discretion in setting the date of trial ${ }^{70}$ should be limited by some form of active judicial supervision, preferably by a judge who has not made the determination to deny bail. An obvious starting place would be to set trial for a fixed number of days after denial of bail. Liberal allowance of continuances could defeat this safeguard, however, and unfortunately there seems to be no more rigorous substitute for judicial discretion in balancing the right to speedy trial against the prosecution's opportunity to build a case.

64. See Appendix.

65. Philadelphia Bail Study 1038-43. "The conclusion is inescapable, therefore, that the real purpose of high bail is to incarcerate defendants ...." id. at 1076.

66. See text at note 28 supra.

67. Cf. Frence Code of Penal Procedure art. 137 (1957-58) (which permits preventive detention as an "exceptional measure"). See generally, Vouin, Provisional Relcase in French Penal Law, 108 U. PA. L. Rev. 355 (1960). See also ALI, Code CrIM. Proc. $§ 70$ (1930).

68. See Current Legislation, 21 Colum. L. Rev. 592, 595 (1921). The sixth amendment to the United States Constitution provides: "In all criminal prosecutions, the accused shall enjoy the right to a speedy and public trial...."

69. On "plea bargaining" generally, see Comment, 66 Y ALE L.J. 204 (1956); Newman, Pleading Guilty for Considerations; A Study of Bargain Justice, 46 J. CRIMr. L., C. \& P.S. 780 (1956).

70. The practice of permitting the prosecuting attorney to prepare and control the trial calendar and to designate the case for trial before a particular judge is not legally subject to objection. See Gleason v. Mullen, 204 Misc. 450, 121 N.Y.S.2d 605 (1953). 
The arguments against this overhaul of the bail system would probably involve differing variations of the "system maintenance" $7 x$ theme. Individualized determination of the conditions imposed on release would take time, and might require the appointment of additional judges. Where financial security is required, handling of the collateral might require the appointment of additional administrative personnel. To be balanced against these added expenses, however, is the likely reduction in the cost of maintaining detention pens, ${ }^{72}$ and the savings arising from permitting the accused to retain his employment, thereby keeping his family off the community relief rolls. ${ }^{73}$ Arguably, the prosecutor would not be able to gain as many guilty pleas because of his loss of bargaining power, and this would mean a consequent increase in litigation. But the only kind of bargaining power which seems at all consonant with the presumption of innocence, is bargaining power based on the accused's fear of conviction; use of the advantage gained from prolonged incarceration before trial lacks even this justification.

71. See Goldstein, Police Discretion Not to Invoke The Criminal Process: Low-Visibility Decisions in the Administration of Justice, 69 Y ALE L.J. 543, 561 n.33 (1960).

72. The total cost to New York City for operating its detention facilities was $\$ 5,183$,857. NYC Dep't of CoRrection, Annual Report 64 (1955), cited in Nez York Bail Study 723.

73. See United States v. Barber, 140 U.S. 164, 167 (1891) ; OrfIELD 102, 131.

\section{Appendix: State Laws Governing the Right to Bail}

1. Thirty-eight states guarantee that: "All persons shall, before conviction, be bailable by sufficient sureties, except for capital offenses when the proof is evident or the presumption great."

ALA. Const. art. I, § 16; ArIz. Const. art. II, $\S 22$; ARK. Const. art. II, $\S 8$; CaL. Const. art. I, $\$ 6$; Colo. Const. art. II, \$ 19; Conn. Const. art. I, \$ 14; DeL. Const. art. I, $\$ 12$; Fla. Declaration of Rights $\$ 9$; Hawair Rev. Laws $\$ 256-3$ (1955); Idaho Const. art. I, § 6; ILl. Const. art. II, § 7; Iowa Const. art. I, § 12; Kan. Const., BILL of Rrghts $\$ 9$; Ky. Const. $\$ 16$; LA. Const. art. I, $\$ 12$; Me. Const. art. I, $\$ 10$; MrnN. Const. art. I, $\$ 7$; Mrss. Const. art. III, $\$ 29$; Mo. Const. art. II, $\$ 24$; Mont. Const. art. III, $\$ 19$; N.H. Rev. Stat. Ann. $\$ 597: 1$ (1955) ; N.D. Const. art. I, \$ 6; Nev. Const. art. I, $\$ 7$; N.J. Const. art. I, $\$ 11$; N.M. Const. art. II, § 13; Онто Const. art. I, § 9; OnLa. Const. art. II, § 8; PA. Const. art. I, § 14; R.I. Const. art. I, § 9; S.C. Const. art. I, $\S 20$; S.D. Const. art. VI, § \&; Tenn. Const. art. I, § 15; TEX. Const. art. I, § 11; Utah Const. art. I, \$ S; Vt. Const. ch. II, \$ 32; Wash. Const. art. I, \$ 20 ; Wis. Const. art. I, $\$ \& ;$ Wyo. Const. art. I, $\$ 14$. Alaska apparently provides for an absolute right to bail. Alaska Comp. Law Ann. $\$ 69-5-1$ (1948).

2. Four states limit the power to deny bail to treason and murder cases.

Ind. Const. art. I, $\$ 17$; Mich. Const. art. II, § 14; Neb. Const. art. I, § 9; Ore. Const. art. I, $\S 14$.

3. Three states grant an absolute right to bail only in misdemeanor cases.

Ga. Code Ans. § 27-901 (1953) ; Md. Ann. Code art. 52, § 13(b) (1951); N.Y. Code Crma. Proc. $\$ 553$.

4. Four states allow judges almost complete discretion, in accord with the common law. Mass. Ann. Laws ch. 276, $\$ 42$ (1956) ; N.C. Gen. Stat. $\$ 15-102$ (1953); VA. Code ANN. $\S \$ 19-88$, to 19-50 (1950); W. VA. CoDE ANN. $\S 6152$. 